\title{
DEVELOPMENT OF LOCAL COMMUNITY-BASED TOURISM POTENTIAL AS AN ALTERNATIVE FOR INCREASING SOURCES OF COMMUNITY INCOME IN KERINCI REGENCY, INDONESIA
}

\author{
Hodijah Siti ${ }^{\star}$, Delis Arman \\ Faculty of Economics and Business, University of Jambi, Indonesia \\ *E-mail: sitihodijah@unja.ac.id
}

\begin{abstract}
The study aims to analyze the potential of tourism objects, tourism development strategies and analyze tourism management as an alternative to increasing the income sources of the Kerinci Regency. The data used consists of primary data and secondary data. The results showed that the Kerinci Regency has many attractions: nature tourism, cultural tourism, history and artificial tourism, and can be a source of income for the community around the tourism object. SWOT analysis results obtained five alternative strategies, namely: 1) management of tourism objects based on the community or surrounding villagers, 2) improving infrastructure and supporting facilities, 3) increasing promotion in utilizing social media, 4) exploring the potential of tourism objects properly and correctly, 5) rates are in accordance with the conditions of the attractions. QSPM analysis shows that the main strategy for increasing the source of community income is the development of attractions with community-based management patterns or local residents.
\end{abstract}

\section{KEY WORDS}

Tourism object, SWOT, QSPM, community, management.

Tourism aims to increase economic growth, eradicate poverty, overcome unemployment, improve people's welfare, preserve nature, the environment and resources, advance culture, uplift the nation's image, strengthen national identity and strength, strengthen friendship between nations. The benefits of the tourism industry can be felt by stakeholders consisting of the government, business world, tourists and related parties have a role in running the industry (Ismayanti, 2010). Tourism has become an industry that influences other aspects of life (Sunaryo, B, 2013). Tourism activities carried out starting from the departure to the destination. Tourism is said to have extraordinary encouragement that can make local people experience cycles in life (Oka AY, 1997).

The tourism objects in Kerinci Regency are very diverse which consist of natural tourism, tourism and artificial tourism. Te number of attractions indicates the potential sources of increasing local people's income if it can be managed optimally. Based on these conditions and problems, it is important to study the development of local community-based tourism potential as an alternative to increasing the source of community income in the Kerinci Regency. Tourism in this area has a lot of tourism potential, both natural tourism potential, artificial or cultural that can be developed into an attractive tourist attraction. But the management and development of tourism potential is still far from optimal. Management and development of tourism objects in the research area are currently not utilized properly and optimally by the government as a tourist destination. The government dose not pays attention to the potential and patterns of tourism development so that many tourists don't know the potential attraction of tourism. For that we need the concept of the direction of the development of appropriate tourism objects in order to obtain optimal results.

Tourism object development is basically a conscious and planned effort to improve existing facilities or add facilities that don't yet exist according to the needs of tourist (Pendit, NS, 1999). In this connection the research aims to determine the distribution of attractions, analyze the potential of attractions and reconstruction of appropriate tourism object development. Assessment of the potential of these attractions is very useful in knowing what potential can explored and developed from existing attractions. Follow-up that can be done is 
an attractions so that their existence can increase the value of these attractions and ultimately can be an alternative source of increasing community income.

\section{METHODS OF RESEARCH}

This research uses primary data and secondary data, primary data regarding information on tourism potentials. Secondary data were obtained from the Kerinci Regency cultural publications and other relevant publications. Primary data is collected directly to the object of research through field surveys. Information gathering was carried out by direct interviews with 60 respondents and 12 informants. The study was conducted in August and September 2018.

The analytical method used is descriptive analysis, and SWOT analysis. According to Udaya, dkk (2013) SWOT analysis is an analysis of strengths, weaknesses, opportunities, threats faced by tourist areas. SWOT analysis method is used to determine the development strategy by analyzing external factors (opportunities and threats) and internal factors (strengths and weaknesses) of the EFE matrix (Wahid, A, 2017, Farida, K, 2017) and IFE. An external factor evaluation (EFE) matrix is used to analyze the opportunity and threat factors encountered. An internal Factor Evaluation (IFE) matrix is used to analyze the strengths and weaknesses they have.

SWOT analysis is carried out in the following stages. Stage of forming the IFE and EFE matrix (Rangkitu, F, 2006, Wahid, A, 2017), namely:

- Make a list of critical success factors for external aspects which include about opportunities and threats and internal aspects in the form of strengths and weaknesses placed in the first column;

- Determine the weight (Weight) of critical success factors. Weight determination is done by submitting identification of internal and external factors using the "Paired Comparison" method.

The scale used for filling in the column is:

- If the horizontal indicator is less important than the vertical indicator;

- If the horizontal indicator is as important as the vertical indicator;

- If the horizontal indicator is more important than the vertical indicator.

Table 1 - Assessment of Internal Strategy Factor Weights

\begin{tabular}{|c|c|c|c|c|c|c|}
\hline Internal Strategy Factors & A & B & C & D & $\ldots$ & Total \\
\hline A & & & & & & \\
\hline B & & & & & & \\
\hline C & & & & & & \\
\hline D & & & & & & \\
\hline$\ldots$ & & & & & & \\
\hline Total & & & & & & \\
\hline
\end{tabular}

Table 2 - Assessment of External Sterategy Factor Weights

\begin{tabular}{|c|c|c|c|c|c|c|}
\hline External Strategy Factors & A & B & C & D & $\ldots$ & Total \\
\hline A & & & & & & \\
\hline B & & & & & & \\
\hline C & & & & & & \\
\hline D & & & & & & \\
\hline$\ldots$ & & & & & & \\
\hline Total & & & & & & \\
\hline
\end{tabular}

Determine the rating of each critical success factor between 1 and 4 , where: for the IFE matrix, rating $1=$ major weaknesses, 2 = small weaknesses, $3=$ small strengths, and $4=$ main strengths. While for the EFE matrix, rating $1=$ below average, $2=$ average, $3=$ above average, 4 = superior. Multiplying the weight value by the rating value to get the score of all critical success factors. Add up all the scores to get the total score. On the IFE matrix the average value is 2,5 . If the value is below 2,5 indicates that internally, the company is weak, while the value is above 2,5 indicates a strong internal position. 
The last stage is the decision-making stage that is using the QSPM matrix (Quantitative Strategic Planning Matrix). (David 2006):

\section{RESULTS AND DISCUSSION}

Kerinci Regency has many tourism objects with very potential to be developed to support tourism activities. Based on the number of attractions, Kerinci Regency has the most natural attractions of other regencies/cities.

Table 3 - The Number of Natural, Man-made and Historical Tourism Object in Several Regencies/cities in Jambi Province (Tourism Object)

\begin{tabular}{|c|c|c|c|c|}
\hline District/City & Nature Tourism & Artificial Tourism & Historical Tourism & Total Tourist Attraction \\
\hline Kerinci & 98 & 10 & 20 & 127 \\
\hline Bungo & 26 & 8 & 13 & 47 \\
\hline Merangin & 20 & 7 & 8 & 35 \\
\hline Jambi City & 3 & 77 & 62 & 142 \\
\hline
\end{tabular}

Source: Jambi Province in Numbers, 2017.

In 2017 the number of natural attractions in the Kerinci Regency was 98 attractions 10 artificial tours and 20 historical attractions. Leading tourism objects in the Kerinci area are the seven mountain lake attractions, Kaco Lake, Kerinci Mountain, Smoky Telun Waterfall, Kerinci lake and Aro wood plantation.

Kerinci Regency Tourism Object Development Strategy:

Strenght (1) The Potential of Many Tourism Objects, Kerinci Regency has relatively many natural, historical and cultural tourism objects which attract tourists from domestic and abroad to travel. (2) Increasing Public Interest in Tourist Objects, community interest to travel increases this is evidenced by the hectic tourist arrivals in new tourism objects developed by the government, private sector and village through village-owned enterprises (BUMDES). (3) Support of Tourism Product in the Form of Food, tourists visiting the Kerinci district can not only enjoy the natural beauty and uniqueness of tourist attractions, they can also enjoy culinary products such as: dodol potatoes, cinnamon syrup and curry fish which add to the excitement when visiting tourist attractions in the district of Kerinci. (4) Diverse Tourism Potentials, natural beauty based tourism potentials; Kerinci Regency also relies on the potential of historical attractions such as the history of the Depati Parbo struggle and the sacred mosque, the potential of health tourism objects in the hot spring and Medang river hot water, educational tourism objects like are wood flower garden. (5) Has the Potential, ecotourism-based tourism potential is also found in the Kerinci Regency, by relying on the wealth of natural resources and soil fertility, the ecotourism destination in the Kerinci Regency is very likely to be developed.

Weakness (1) Management of tourist objects is not managed properly, tourism objects in the district of Kerinci have not been well managed, especially from the aspects of management, maintenance of objects to the marketing of attractions, causing tourism object to be unable to become the driving sector of economic activity (2) Government supports is very limited, so that now government support for tourist objects to encourage tourism service provision activities (3) Low community participation is still very low, so the tourism sector is unable to become the main sector driving the economy in the service sector (4) infrastructure facilities are limited, tourist infrastructure is still very limited when compared to the potential of tourist objects, especially road facilities, lodging and main facilities supporting tourism both towards tourism objects and at tourist attractions. (5) The technology that has not been utilized for the promotion of tourist objects, social media is currently an opportunity for the government to promote tourism objects in order to attract tourist visits.

Opportunities (1) Can increase the income of the local community, the local community can feel the direct impact of tourism activities, with the visit of tourist it can directly create economic activities to meet the needs of tourist so that the local community can take advantage of the provision of tourism services to making souvenirs for tourist so that 
increase people's income, (2) increasing the receipt of vacations fees, the economic impact of tourism activities can increase local revenue through entertainment fees, tourism is also able to increase the contribution of regional revenues for development in the district of Kerinci, (3) opportunities in increasing the source of community income from tourist activity activities, the tangible benefit of tourism activities are being a tour guide, leasing home stays up to being an officer at each tourist attraction, (4) increasing foreign exchange opportunities from foreign tourist, every foreign tourist who visits will generate foreign exchange for the country, the greater the number of foreign tourist who come it will increase foreign exchange earnings for Indonesia, which is very necessary so that the tourism sector becomes a driving force for the Indonesian economy, (5) can be a leading tourist attraction from other attractions, the uniqueness and beauty of tourist objects in the regency of Kerinci become added value compared to tourist objects in other areas, so that existing attractions can be used as superior tourist objects compared to attractions in other areas.

Threats (1) The development of other regional tourism objects, the closest regencies such as Merangin regency and West Sumatera Province pose a threat to the development of tourism objects in the Kerinci Regency, considering that these areas also have unique attractive tourist attractions (2) the high tariff of entering a tourist attraction, the attraction of a tourist attraction that is too high causes the interest of tourists to visit will also be reduced, because tourists feel the satisfaction obtained is not proportional to the tariff that must be paid (3) Increased infrastructure in other regions, good tourism infrastructure to other regions is a threat to the development of tourism objects in the regency of Kerinci, considering that infrastructure is one of the main components in tourism facilities (4) The low tariff for tourist objects in other regions, the object tariff is something that is sensitive for tourists, moreover the value paid is not in accordance with the satisfaction obtained, it will cause tourists to be reluctant to visit Kerinci regency attractions.

Table 4 - Internal Factor Evaluation Matrix (IFE)

\begin{tabular}{|c|c|c|c|c|}
\hline No & External Strategy Factors & Weight $(A)$ & Rating (B) & Score $(A \times B)$ \\
\hline \multicolumn{5}{|c|}{ Strength } \\
\hline 1. & The potential of many attractions & 0,07 & 3,75 & 0,26 \\
\hline 2. & Increasing public interest in attractions & 0,08 & 3,23 & 0,26 \\
\hline 3. & Support tourism products in the form of food & 0,088 & 3,12 & 0,27 \\
\hline 4. & The potential of diverse attractions & 0,094 & 3,76 & 0,35 \\
\hline 5. & Has the potential of attractions based on ecotourism destinations & 0,08 & 3,07 & 0,25 \\
\hline \multicolumn{5}{|c|}{ Weaknesses } \\
\hline 1. & Management of attractions that are not managed properly & 0,12 & 1,56 & 0,18 \\
\hline 2. & Limited government support & 0,116 & 1,98 & 0,19 \\
\hline 3. & Low community participation & 0,099 & 2,02 & 0,24 \\
\hline 4. & Low infrastructure facilities & 0,122 & 2,01 & 0,12 \\
\hline 5. & Technology has not been utilized for the promotion of tourist attractions & 0,12 & 2,06 & 0,25 \\
\hline \multicolumn{2}{|r|}{ Total } & 1,00 & 25,59 & 2,53 \\
\hline
\end{tabular}

Table 5 shows that the total score of the type matrix is 2,53 . This value indicates that the tourism object has a strong internal position because the score value is above 2,5 . The main strengths of attractions, the potential of diverse attractions $(0,35)$ and other strengths that are based on the score value are the diversity of attractions $(0,27)$, the potential of diverse attractions $(0,26)$, increasing public interest in tourist objects $(0,26)$, and has the potential for attractions based on ecotourism destinations $(0,25)$. The main weaknesses of the management of attractions that are not managed properly $(0,18)$ and other weaknesses that are owned based on the score are very limited government support $(0,19)$, low infrastructure facilities $(0,244)$, low community participation $(0,245)$, untapped technology for promotion of attractions $(0,25)$.

Table 5 shows that the total score of the EFE matrix is 2,77. This value indicates that the tourist attraction can be said to be able to take advantage of external opportunities and avoid existing threats. The main opportunities for attractions to increase the reception of entertainment fees $(0,47)$ and other opportunities obtained are the creation of opportunities to increase sources of community income from tourist attraction activities $(0,46)$ can increase the income of the surrounding community $(0,35)$, increasing the country's foreign exchange 
opportunities from foreign tourist $(0,33)$ can make a leading attraction of attraction $(0,31)$. Threat of attractions is the development of attractions in other areas $(0,23)$ and other threats obtained based on the score is the development of attractions on other areas $(0,23)$ low tourist attractions rates in other areas $(0,22)$, high rates entering tourist attraction $(0,17)$.

Table 5 - External Factor Evaluation Matrix (EFE)

\begin{tabular}{|c|c|c|c|c|}
\hline No & External Strategy Factors & Weight $(A)$ & Rating (B) & $\begin{array}{l}\text { Score } \\
\text { (AxB) }\end{array}$ \\
\hline \multicolumn{5}{|c|}{ Opportunity } \\
\hline 1. & Can increase the income of the surrounding community & 0,09 & 3,75 & 0,35 \\
\hline 2. & Increase the reception of entertainment fees & 0,13 & 3,65 & 0,47 \\
\hline 3. & $\begin{array}{l}\text { The creation of opportunities in increasing the source of community income } \\
\text { from tourist activity }\end{array}$ & 0,13 & 3,58 & 0,46 \\
\hline 4. & Increased foreign exchange opportunities for foreign tourists & 0,12 & 2,68 & 0,33 \\
\hline 5. & Can make a leading tourist attraction from other attractions & 0,10 & 3,05 & 0,31 \\
\hline \multicolumn{5}{|c|}{ Threat } \\
\hline 1. & The development of attractions in other areas & 0,11 & 2,04 & 0,23 \\
\hline 2. & High entrance fee for attractions & 0,08 & 2,05 & 0,17 \\
\hline 3. & Improved infrastructure in other regions & 0,11 & 2,15 & 0,23 \\
\hline 4. & Low tourist attraction rates in other areas & 0,12 & 1,82 & 0,22 \\
\hline \multicolumn{2}{|r|}{ Total } & 1,00 & 24,77 & 2,77 \\
\hline
\end{tabular}

Matching stage (IE matrix and SWOT matrix). IE matrix is a combination of the results of the EFE matrix and EFE matrix. IE matrix makes it easier to provide alternatives in the face of competition. The value of the IFE matrix and EFE matrix are obtained from the total score of each matrix where in the IFE matrix the total score is 2,53 and the EFE matrix is obtained a score of 2,77 which if the value is mapped into the matrix IE is ion quadran V.IE matrix map can be seen in figure 1.

\begin{tabular}{|c|c|c|c|c|}
\hline & & TOTAL SCC & E IFE & \\
\hline & & Strong & Average & Weak \\
\hline & & 3,0 & 2,0 & 1,0 \\
\hline & $\begin{array}{c}4,0 \\
\text { High } \\
3,0\end{array}$ & $\begin{array}{c}\text { I } \\
\text { Grow and Build }\end{array}$ & $\begin{array}{l}\text { II } \\
\text { Grow and Build }\end{array}$ & $\begin{array}{c}\text { III } \\
\text { Hold and Mantain }\end{array}$ \\
\hline TOTAL & Average & & 回 & \\
\hline SCORE & & IV & V & VI \\
\hline EFE & $\begin{array}{l}2,0 \\
\text { Low }\end{array}$ & Grow and Build & Hold and Mantain & $\begin{array}{l}\text { Harvest and } \\
\text { divestitue }\end{array}$ \\
\hline & 1,0 & $\begin{array}{c}\text { VII } \\
\text { Hold and } \\
\text { Mantain }\end{array}$ & $\begin{array}{c}\text { VIII } \\
\text { Harvest and } \\
\text { divestitue }\end{array}$ & $\begin{array}{c}\mathrm{XI} \\
\text { Harvest and } \\
\text { divestitue }\end{array}$ \\
\hline
\end{tabular}

Figure 1 - Matrix Analysis Results IE

Figure 1 shows that the development of Kerinci Regency tourism object is located in the hold and Maintain position. Hold and Maintain can be seen from the factors of strength and opportunities. The strength factor is a factor that must be maintained while the opportunity factor is a factor that must be maintained.

Matrix Strengths, Weaknesses, Opportunities, and Threats (SWOT). SWOT matrix is an important matching tool in developing four types of strategies namely the S-O strategy (strength-opportunity), W-O strategy (Weaknesses-opportunity), S-T strategy (strengththreat), and the strategy of W-T (weaknesses-threat). SWOT matrix can be arranged based on the results of identification of the IFE matrix and the EFE matrix by describing strengths, weaknesses, opportunities, and threats. These alternative strategies can be seen in table 6 .

From the analysis of what the strengths, weaknesses, opportunities, and threats five alternative strategies namely:

- Strategy S-O, Management of tourism objects is based on the local community or village In order for tourist objects to be of benefit to the local community, attractions should be managed by the community or village so that the receipt of retribution can be used for the development of tourism objects and village development needs. 
- Strategy W-O, (1) improve infrastructure and supporting facilities, the government is expected to improve infrastructure and facilities supporting tourist attractions so that tourists feel comfortable, such as places of worship, toilets, canteens and other facilities that support tourist attractions. (2) Increase promotion by utilizing social media. Promotion is very important in the development of tourism objects because of the promotion of many people can know the attractions. social media needs to be utilized maximally for promotion.

- Strategy S-T, Exploring the potential of tourism objects properly and correctly. The potential of an object can hold has not been maximally managed. Tourist attractions have not been addressed properly.

- WT Strategy, adjust rates to the conditions of attractions. Rates to attractions become a very important factor in tourism development. Rates should be adjusted to the condition of attractions and the completeness of the supporting facilities.

Table 6 - Results of the SWOT matrix analysis

\begin{tabular}{|c|c|c|}
\hline External Analysis & $\begin{array}{l}\text { Power (S): } \\
\text { Potential attractions; } \\
\text { Tourist interest in attractions; } \\
\text { Culinary product support for tourists; } \\
\text { The potential of diverse attractions; } \\
\text { Has the potential for tourism based } \\
\text { on ecotourism destinations. }\end{array}$ & $\begin{array}{l}\text { Weakness }(\mathrm{W}) \text { : } \\
\text { Management of attractions } \\
\text { that are not good; } \\
\text { Government support is very } \\
\text { limited; } \\
\text { Society participation; } \\
\text { Limited infrastructure } \\
\text { facilities; } \\
\text { Limited tourist object } \\
\text { promotion. }\end{array}$ \\
\hline $\begin{array}{l}\text { Opportunity (O): } \\
\text { Increased income of the community around; } \\
\text { Increase user acceptance; } \\
\text { Opportunity to increase sources of community income } \\
\text { from tourist attraction activities; } \\
\text { Foreign exchange opportunities; } \\
\text { Become a national flagship tourist attraction. }\end{array}$ & $\begin{array}{l}\text { Strategy S-O: } \\
\text { Tourist object managed by the } \\
\text { community or village (S2, S3, O1, } \\
\mathrm{O} 2, \mathrm{O} 3, \mathrm{O} 4, \mathrm{O} \text { ). }\end{array}$ & $\begin{array}{l}\text { Strategy W-O: } \\
\text { Improve infrastructure (W1, } \\
\text { W4); } \\
\text { Increase promotion by } \\
\text { utilizing social media (W5, } \\
\text { O5). }\end{array}$ \\
\hline $\begin{array}{l}\text { Threat }(T) \text { : } \\
\text { The development of Agia could have been in other } \\
\text { areas; } \\
\text { The high tariff to enter a tourist attraction; } \\
\text { Improvement of infrastructure in the low tourist } \\
\text { attraction rates in other areas regions; } \\
\text { Low tourist attraction rates in other areas }\end{array}$ & $\begin{array}{l}\text { Strategy S-T: } \\
\text { Explore the potential of tourism } \\
\text { objects well (S1, S2, S3, S4, S5, TI, } \\
\text { T3). }\end{array}$ & $\begin{array}{l}\text { Strategy } \mathrm{W}-\mathrm{T} \text { : } \\
\text { Adjust tourist object rates with } \\
\text { conditions (W1, W4, T2, T5). }\end{array}$ \\
\hline
\end{tabular}

Decision Stage (QSPM Matrix). The last stage in formulating a strategy is the decision stage using Quantitative Material Strategic Planning Matrix (QSPM) which aims to evaluate alternative strategies that are most likely to be implemented first. The strategies created based on the position of the IE matrix are then formulated into the SWOT matrix; the SWOT matrix is re-evaluated to face opportunities and threats with its strengths and weaknesses.

The final result of your QSPM analysis in the form of Total Attractiveness Score (TAS) or total attractiveness score is the sum of the results of multiplication of attractiveness scores (AS), namely the strategy of internal or external factors with an average weighting of internal and external factors that have been formulated in the IFE and EFE matrices. STAS value is the value of the total value of the bag. After getting the value of the STAS, then sorted the STAS value from largest to smallest. The highest STAS value is a priority strategy that must be carried out.

Based on the QSPM calculation, the highest STAS value is the management of tourist objects based on the community or local village of 6,16 , while the other alternative strategy is to explore the potential of tourism objects properly and correctly (value of STAS 6.08), Improving infrastructure and supporting facilities (value of STAS 5.65), increase promotion by utilizing social media (value of STAS 4,93) and adjust rates to the conditions of attractions (value of STAS 4,73). The choice of the main alternative strategy, which is the management of tourism objects based on the local community or village is the right strategy for the development of attractions, because it will increase the income of the people who are around these attractions. 
Pattern of Management of Tourism Maps as an Alternative to Increasing Sources of Community Income. Well-managed natural tourism objects can produce many economic benefits and have little impact on protected forest areas and environmental preservation. Some tourism objects in the Kerinci regency have varied management; some are managed by the government, community or personal. Tourist attraction Danao Gunung Tujuh, Lake Kaco, Kerinci Mountain, Smoky Waterfalls, Lake Kerinci, Aro Wood Tea Plantation is not facilitated with good facilities and infrastructure and does not involve many people around the tourist attraction.

From these various management patterns it must involve the surrounding village community, and the management of tourism that is balanced and environmentally sustainable. the management pattern of community-based tourism is expected to be able to increase community income both directly and indirectly, through various businesses related to tourism development and can expand and create new jobs. The increasing number of tourist visits, means that the increase in tourist spending has an impact on the increased demand for goods and services needed. Therefore, it will open up opportunities for local people to become hoteliers, guesthouses, home stays, food stalls, transportation and other services. this employment can increase income to support the household life of the community. Management of attractions by the public is smooth with the help of government and non-governmental and private organizations.

\section{CONCLUSION}

Kerinci Regency has many tourism objects that are very potential to be developed for tourism and can be a source of income for the community around the tourist attraction. The QSPM results show that the main strategy is to maintain tourism objects by managing tourism objects based on the surrounding community or local village. The pattern of management of local community-based tourism as an alternative to increasing the source of community income because it will open up opportunities for local communities to become hoteliers, home stay guesthouses, food stalls, transportation and other services. This employment can increase income to support the household life of the community. The policy that needs to be done is the development of attractions and attractions, the development of amenetas and tourist accommodation, accessibility and image development.

\section{REFERENCES}

1. Ismayanti.2010. Introduction to Tourism. Jakarta: PT Gramedia Widisarana.

2. Farida, K. (2017). Increasing Community Income through Tourism Activities on the Marina Coast of Bantaeng District. Tourism Journal, volume 11, No 01 February 2017; pages 31-43.

3. Oka, A. Yoeti, (1997). Tourism Planning and Development, Jakarta, PT. Pradnya paramita.

4. Pendit, Nyoman S, (1999), Tourism Science; a Prime Introduction, Jakarta, PT. Pradnya paramita.

5. Ranil, D.P,dkk. 2014. The Development of the Tourism Potential of Sumenep Regency. Young Political Journal, vol. 3, no 3, 412-424.

6. Rangkuti,freddy, (2006), SWOT Analysis of Case Surgery Techniques, Jakarta, PT. Gramedia.

7. Sunaryo, B. (2013). Concept Tourism Development Policy and Its Application in Indonesia. Yogyakarta: Gava Media.

8. Wahid, Abdul, (2015), West Nusa Tenggara Tourism Development Strategy Towards the Main Islamic Tourism Destination, Thesis Majoring in Economics Faculty of Economics, University of Muhammadiyah Yogyakarta. 